\title{
Advertising for Beer: Local Identity and the Klondike Brewery, | 900-1920
}

\author{
Heather Green \\ Saint Mary's University, Halifax \\ Matt Papai \\ Memorial University of Newfoundland
}

\begin{abstract}
Yukon entrepreneur Thomas O'Brien opened the O'Brien Brewing and Malting Company, better known as the Klondike Brewery, in Klondike City in 1904, after the population of Dawson City had dramatically declined following the end of the Klondike Gold Rush (1896-1899). O'Brien's decision to open a new business following the gold rush reflected his hope that Dawson would continue to develop and modernize, and O'Brien intended to be part of this growth. The Klondike Brewery operated from 1904 to 1919 and was the first brewery in northern Canada. Local newspapers - the Yukon Sun and the Dawson Daily News - frequently reported on the progress and activities of the brewery during its construction and operation, and O'Brien took advantage of the media to advertise his products. He used both his brewery and its promotion to highlight not only what was special about his products, but also what he believed Dawson's future could be.These ads emphasized the beer's homegrown origins, they celebrated Klondike beer using Klondike cultural imagery, and they emphasized the brewery's modern nature. O'Brien not only sold beer, but he sold an idea to those who remained after the rush. We argue that the ways in which O'Brien branded and marketed his products, specifically his beer, tapped into a developing sense of local cultural identity among the post-gold-rush settler population in Dawson City, and that O'Brien used his brewery to shape his idea of Dawson's potential future.
\end{abstract}


Craft beer and the breweries that create them have been growing in popularity globally since the early 1980s. Geographer Derreck Eberts described microbreweries as "tools of local identity which help to reconnect people with the places in which they live." ${ }^{1}$ Through a process labelled "neo-localism," Eberts argues, microbreweries invoke geography and place in their branding and marketing. This branding and marketing technique was no different in the Klondike region of the Yukon Territory between 1904 and 1919 when the O'Brien Brewing and Malting Company, more commonly known as the Klondike Brewery, operated.Today, microbreweries utilize neo-localism within their marketing strategies. For example, Yukon Brewing in Whitehorse has several beers alluding to history and place in the Yukon using names such as "Chilkoot," "Midnight Sun," "Lead Dog Ale," "Yukon Gold," and "Bonanza Brown" (http://yukonbeer.com). The Klondike Brewery was an early example of a microbrewery in Canada's North using similar neo-localism strategies. The language that owner Thomas O'Brien used in the advertisements he placed in local newspapers, such as the Yukon Sun and the Dawson Daily Nerws, fits Eberts's concept of neo-localism, suggesting that the Klondike Brewery was an early example in the long tradition of breweries attempting to connect their beer with sense of place and local identity.

Anthropologist Mary Douglas has argued that the consumption of alcohol is, like other collective practices, an action in which identity is constructed and boundaries of inclusion and exclusion are formed. ${ }^{2}$ This seems to have been the case in Dawson during and following the gold rush. Saloons were the most common meeting place-for non-Indigenous people - and acted to shape who was included in planning Dawson's future development and who was excluded. Breweries in other gold rush towns emerged with the influx of miners - as was the case with Circle City, Alaska, which had three breweries and twenty-eight saloons. ${ }^{3}$ However, there was no permanence to these breweries and they quickly closed once local mining populations moved to the next gold rush. Where most breweries were a flash-in-the-pan reaction to a large population influx, O'Brien seems to have built something different in Dawson City.

Our study of the Klondike Brewery expands on the 2002 work of archaeologists David Burley and Michael Will—one of the only published works that focuses explicitly on the brewery. ${ }^{4}$ In their work, Burley and 
Will discuss the brewery as a symbol of future prosperity and they briefly examine marketing techniques employed by O'Brien. Though Burley and Will draw out some themes they see emerge from these ads, and devote a paragraph to discussing Klondike Brewery advertisements, their focus is on the industrial archaeology of this brewery. ${ }^{5}$ It is our intention to examine these same advertisements and marketing techniques to gain better insight into the ways in which O'Brien relied on concepts of neolocalism. We argue that the ways in which O'Brien branded and marketed his products, specifically his beer, tapped into a developing sense of local cultural identity among the post-gold-rush settler population in Dawson City, and that O'Brien used his brewery to shape his idea of what Dawson's future could be.

\section{Drinking in Dawson After the Gold Rush: The Klondike Brewery}

Most people who went to the Klondike went for gold, but entrepreneurs were just as important to gold rush narratives as miners- they saw the gold rush as a possibility to capitalize on miners' needs for goods and services. ${ }^{6}$ In the first winter of the gold rush (1896-97), the town of Dawson was made up of Indigenous locals-primarily the Tr'ondëk Hwëch'in-and those miners and prospectors who were already up North. But by the summer of 1897 the Klondike stampede brought a population explosion of "cheechakos" - a contemporary Chinook term for newcomers- to the Yukon, providing the opportunity for entrepreneurs to start businesses serving the miners. ${ }^{7}$ Saloons and bars were the most plentiful, and most popular, businesses in Dawson beginning in 1897.

Historian Max Nelson has argued that "the consumption of alcohol is usually very strongly embedded in socio-cultural ideologies since they tend in most societies not to be solitary activities but social ones performed in a social context." ${ }^{8}$ During the gold rush years, Dawson City's population consisted of predominantly young, male, and transient people; to this demographic saloons were not only important for relaxation and social life, but also for learning the news-in the case of Dawson, news of the next gold rush or learning when claims had all been staked. ${ }^{9}$ Similar to mining regions elsewhere, pubs and saloons were a staple to social life in Dawson (see Figure 1). 


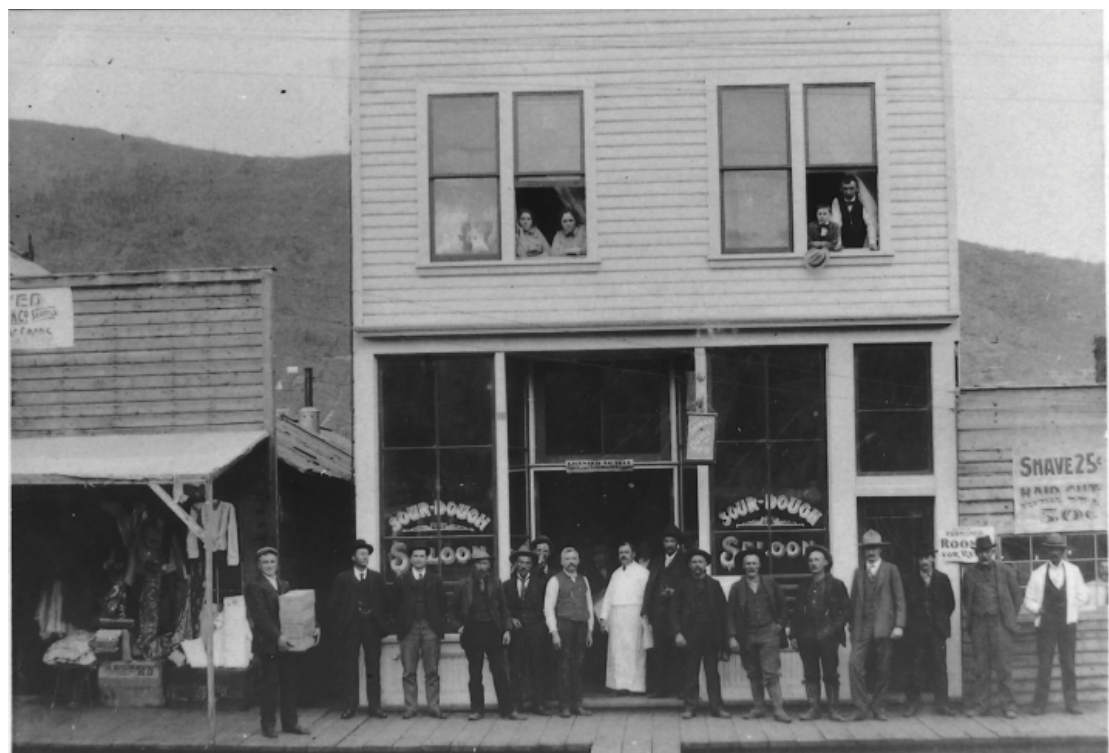

Figure I.A group of men standing outside the Sourdough Saloon, Dawson, 1900. Also visible are two women, one man, and one child looking from the windows of the hotel above the saloon. DCMA 1981.1.2.23.

Historians have examined the role of the saloon and the tavern in contributing to the formation of social life and class consciousness. ${ }^{10}$ In her study of American beer history, historian Amy Mittelman argues that "the quintessential saloon, as distribution outlet, seemed to occur most often in two situations, the frontier town and the industrial city."11 Though Dawson was not an industrial city, it was considered by contemporaries, and many historians who write about it, as a frontier. ${ }^{12}$ Those who went to the Klondike perceived it as unsettled land at the edge of civilization. Many stampeders who wrote of their experiences in the Klondike discussed typical frontier ideologies, such as the conquering of land and environment, and the frontier as a masculine space. Like many "frontier" areas, bars and saloons played an important role in the Klondike's social life and social relations. There, people met friends, exchanged information, made business deals, and talked politics. Saloons in Dawson also served as a form of social welfare in times of unemployment, each winter providing food and shelter to the destitute after closing time. ${ }^{13}$

Saloons' popularity continued after the rush; Lord Minto, who visited Dawson in 1900, remarked that "every third house [building] was a saloon." ${ }^{14}$ Saloons retained their societal and cultural value in post-gold- 
rush Dawson, with many establishments becoming synonymous with political parties and as sites of planning for Dawson's future. For example, because of O'Brien's association with the Liberal Party in Dawson, the group held their meetings at the brewery and they became known as the "Steam Beers," maintaining the brewery as the Liberals' home base throughout O'Brien's affiliation with the party. ${ }^{15}$ While the culture of alcohol consumption and spending time in saloons was an essential aspect of Dawson at this time, as well as part of Dawson's historical image, it is important to note that the saloon culture was fostered for the settler population in Dawson; not everyone was invited to participate.

In her study of taverns in Upper Canada, historian Julia Roberts argues that taverns were both public spaces where people could relax racial boundaries but also spaces where they were strictly enforced. ${ }^{16}$ For Roberts, tavern life was very much concerned with forging a sense of belonging, a practice that often entailed hostility and violence towards "othered" groups, and that these practices reflected the mixed nature of Upper Canadian society; the tavern serves as a window on "wider social and cultural patterns." ${ }^{17}$ People of various ethnicities and genders met in the saloons in Dawson, to varying degrees of inclusion, but the Indigenous populations in the Yukon were excluded. A detailed analysis of the legal relationships between alcohol consumption and Indigenous populations in the Yukon is outside the scope of this article; however, some facts are required to demonstrate how saloons, and the Klondike Brewery, acted as venues of exclusion for Indigenous peoples in Dawson.

The discriminatory image of the "drunken Indian" informed settler perceptions about alcohol consumption and about Indigenous peoples. The stereotype was established as early as the nineteenth century; it reflected the fact some Indigenous peoples engaged in excessive drinking when first exposed to alcohol but, more so it reflected settlers' anxieties about Indigenous peoples and their place in mainstream society. In 1835, the British colonial government passed the Act to Prevent the Sale of Spiritous Liquors to Indians - this regulation influenced Indigenous participation in tavern social life based on their race, and it emphasized their place on the margins of public life by "delegitimizing their participation in one of its everyday locales." 18 This exclusion continued with the implementation of the Indian Act of 1876, which further enforced the illegality of Indigenous peoples consuming alcohol and of anyone supplying or selling alcohol to them anywhere in Canada. ${ }^{19}$ These racial ideologies associated with 
drinking were reflected in the spatial venues of consumption in Dawson. ${ }^{20}$ Just as Indigenous peoples were banned from consuming alcohol under the Indian Act, they were also not permitted to enter local liquor establishments unless they were enfranchised. ${ }^{21}$ Where non-Indigenous men and women congregated in saloons and pubs, which acted as political gathering sites, sites of community, and sites of economic exchange, Canadian law kept Indigenous people out, relegating them to the margins of daily socioeconomic and cultural interactions. ${ }^{22}$

While drinking alcohol and spending time in saloons was a large aspect of life for many people living in Dawson during the gold rush and the decades after, drinking beer was an expensive hobby. Before the Klondike Brewery opened, saloon owners shipped beer long distances from southern Canada and the Lower 48, which raised its cost for barkeepers and customers alike. Imports from cities such as Seattle and Vancouver could run as high as $\$ 1,580$ in 1903 for thirty cases of beer (with approximately $\$ 400$ in shipping fees on top of product price). ${ }^{23}$ The challenges of shipping into the Yukon limited deliveries to after spring breakup when ships could reach Dawson, leading to constricted supply over the winter months. ${ }^{24}$

Not everyone in Dawson was pleased with the frequent consumption of alcohol, and prohibition and temperance movements impacted the liquor industry in the Yukon as early as 1897. Prohibitionists began the Eldorado Bottling Works in Dawson in 1897 and it operated until 1901. The company made syrups, ciders, ginger ale, sarsaparilla, lemon, cream, and strawberry sodas, along with mineral water. The Eldorado Bottling Works delivered to homes and businesses within Dawson and set up a mail order business to the goldfields in order to encourage Dawsonites to choose non-alcoholic options. ${ }^{25}$ Once the population of Dawson declined following the gold rush, as indicated in Table 1, further tension emerged in Dawson regarding alcohol consumption. Prohibitionists and temperance reformers lobbied to limit-or eliminate-the number of saloons and liquor licences in Dawson. ${ }^{26}$ Saloon keepers also petitioned the government in 1905 to limit the number of licensed saloons in order to keep themselves competitive. ${ }^{27}$ In July of 1902, the Yukon Territorial Government issued a Liquor Ordinance that led the number of saloon licences to decrease in favour of licensing hotels. ${ }^{28}$ In 1900 there were nine hotels and twenty-three saloon licences granted; in 1901, twelve hotels and twenty-two saloon licences; and in 1902, thirty hotels and twenty-one saloon licences. 
Table I.Yukon population data, 1898 to $1921^{29}$

\begin{tabular}{cc}
\hline Year & Total Yukon Population \\
1898 & 40,000 \\
1901 & 27,219 \\
1911 & 8,512 \\
1921 & 4,157 \\
\hline
\end{tabular}

With the population decline, southern companies no longer considered Dawson a healthy market and it became costlier, and more difficult, for saloon owners to ship in beer. The cash book from Simon McDonald's popular Red Feather Saloon, which opened in 1902, shows that by 1907 all his beer purchases were local to the Yukon where previously he imported from the southern United States, southern Canada, and Skagway. ${ }^{30}$ The expensive rates for imported beer were further amplified when the Yukon Territorial Government amended regulations in favour of local brewers, like O'Brien's brewery. In 1907, the Yukon Council passed a memo in which a tax of fifty cents per gallon was levied on foreign beer beginning in November of 1908, in an effort to protect home industries. ${ }^{31}$ Though the Klondike Brewery still faced competition with other Canadian breweries, this law helped eliminate competition from the United States and Europe. With a somewhat unsteady climate for beer drinking in Dawson after the gold rush, O'Brien decided to open a brewery nonetheless. O'Brien had existing businesses which he established during the gold rush-the Yukon Pioneer Trading Company store, a tramway, and the Klondike Mines Railway-but choosing to open a brewery once the population declined is indicative of O'Brien's belief that Dawson would continue to develop and expand into the future. While there are no sources that explicitly lay out O'Brien's vision for the future, his involvement in Dawson industry and politics suggests that he believed Dawson's economy would grow. All levels of government, and most individuals living in Dawson after the rush, considered mining to be the future of the Yukon. Gold production in the Yukon increased after the gold rush even though the population of miners declined. This was due to the shift from placer mining to industrial mining after 1906. The year 1908 saw the beginning of a slow and steady rise in production until 1914, with peak production in 1913 when the Yukon 
Gold Company and the Canadian Klondyke Mining Company mined nine tons of gold, combined. ${ }^{32}$ This increase in gold production paralleled O'Brien's beer production, and it is likely that increased mining seemed to promise a profitable future for business in the Klondike region.

While southern companies no longer targeted Dawson as a market, Thomas O'Brien knew there remained a demand for beer among the post-gold-rush settler population and took advantage of decreased foreign supply and accessibility. O'Brien, an entrepreneur and prominent economic and political figure in Dawson from the late 1880s until his death in 1916, identified this post-gold-rush settler population as a ready market for beer and in 1904 he formed the O'Brien Brewing and Malting Company along with five investors including Dr. Alfred Thompson, a member of the Liberal Party, and Edward "Black" Sullivan, an old friend of O'Brien's from Forty Mile. ${ }^{33}$ Before his brewery, he had been involved in retail trade and the sale of liquor at his store. ${ }^{34} \mathrm{O}$ Brien built his new brewery in Klondike City - an area at the confluence of the Yukon and Klondike rivers on the outskirts of Dawson. ${ }^{35}$ When construction of the brewery began in 1904, the announcement was heralded in the Yukon Sun with great aplomb, announcing, "Dawsonites May Tipple Before Spring" and "Brewery Nearly Ready to Brew: It Will be a Great Institution." 36 Part of the general excitement was certainly for the novelty of a local brewery and the expectation of local industry. This was no amateur operation that O'Brien had brought to Dawson City, but included O'Brien's original store property, to act as the main space for brewing, and a newly built adjacent building holding the boiler room to power the brewery. The back of O'Brien's former store held vats and hot water tanks, and the front, cooling tanks and five 2,000 gallon storage tanks. ${ }^{37}$ O'Brien reported in the Yukon Sun that he anticipated his brewery could produce 15,000 gallons of beer per day-though it never actually produced that much-more than enough to wet the whistle of Dawson's population. ${ }^{38}$

It was clearly O'Brien's design to expand his market beyond Dawson, as the mission of the brewery is spelled out within one of his ads in the Yukon Sun, which stated "all downriver trade will naturally fall to the institution [the brewery]," as his beer would be cheaper than the competition. ${ }^{39}$ If the brewery's mission is to be taken literally, this would mean following the Yukon River through Alaska to its mouth in the Bering Sea. However, whatever the intended market, it was clear the brewery meant to provide 
its product not only to local Dawson consumers, but to those outside Dawson wishing to imbibe. Another possibility is that the mere mention of the capability of the brewery and its intention to distribute far beyond Dawson might have been a rhetorical approach to add excitement to its opening. In reality, there is no evidence that Klondike beer ever moved outside of Dawson.

The Klondike Brewery operated from 1904 to 1919 producing steam beer, lager, bock, porter, ginger beer, and champagne cider. The brewery also produced non-alcoholic drinks such as ginger ale, cream and lemon soda, aerated water, and sarsaparilla, and it sold imported cigars. O'Brien also sold his products wholesale to saloons, hotels, and retail outlets. By the end of 1904, O'Brien's beer (the only local option) was outselling imported beer in the most popular saloons in Dawson, such as the popular MacDonald's Saloon, which bought exclusively from O'Brien by $1907 .{ }^{40}$ Before the Klondike Brewery began operating, the most commonly available beer in Dawson was Lemp's Beer from St. Louis. The Klondike Brewery was cheaper than imported beer, going for between twenty-five to fifty cents a bottle as opposed to $\$ 1.00$ a bottle for other brands. ${ }^{41}$

The opening of a new business when others were closing may have contributed to a positive opinion of the brewery among Dawsonitesrecords that discuss individual reception of the brewery are minimal. However, it is reasonable to suggest, based on the production of 289,000 gallons of beer in its first five years of operation, that the brewery was a welcome addition to Dawson. ${ }^{42}$ Burley and Will argue that, in 1904, the Klondike Brewery, "formed a symbol of stability and a verification of the town's anticipated prosperity." ${ }^{33}$ In the post-gold-rush community, the Klondike Brewery was considered a large employer, employing thirteen men throughout its lifespan and fifteen for most of the year in 1909. According to the Dawson Directory, O'Brien's sons Henry and James were employed as bottlers from 1910-1917 and his son Charles as bookkeeper from 1916-1917.

The lower cost of local beer, the limitations placed on imported beer, the restrictions under the Liquor Ordinance discussed earlier, and the hope for future growth and employment all contributed to the early success of the Klondike Brewery. O'Brien, an established businessman, also worked to draw customers to his product by frequently printing advertisements in 
local newspapers, which highlighted what he perceived was special about his products-their relation to a specific post-gold-rush Yukon identity.

\section{Neo-Localism and the Klondike Brewery}

Throughout the course of the brewery's life, O'Brien used newspaper advertisements and reports to drum up interest and business. Before the brewery opened in 1904, O'Brien regularly printed updates in his own newspaper-the Yukon Sun-on the progress of the brewery, and he created anticipation for its opening day in April of $1904 .{ }^{44}$ O'Brien was confident in his product early on, suggesting in the Yukon Sun that his beer "will make the Pabst article taste like soda water without any soda in it" and will sell at a price that will allow his company to "put any other beer out of contest." ${ }^{45}$ His competitor, the Dawson Daily News - the most widely read paper at the time-also printed Klondike Brewery ads and reported on its activities. Once the brewery opened in 1904, the Yukon Sun and Dawson Daily News printed advertisements and reports on the brewery until 1917. These ads emphasized the beer's local and homegrown origins, celebrated Klondike beer using Klondike cultural imagery, and emphasized the brewery's modern nature. Two common themes present themselves within O'Brien's Klondike Brewery advertisements, reflecting on the history of the brewery itself: the first emphasized how Dawson continued to develop and thrive after the gold rush, and the second was how O'Brien's brewery promotion attempted to contribute to post-gold rush society and identity in Dawson.

In ads that evoked a sense of place, O'Brien emphasized the brewery's "homegrown" origin, even though he frequently advertised that he purchased ingredients from outside the territory. Geographers Jay Gatrell, David Nemeth, and Charles Yeager argue that the geography (and history) of brewing and beer has been linked to natural resources and the location of critical inputs, such as rivers. Ideally, industry "seeks to optimize production by identifying locations that minimize transportation costs." ${ }^{46}$ For O'Brien, it was not possible to place his facility in a location that would minimize transportation costs. Dawson faced certain limitations of isolation that other contemporary breweries did not, forcing O'Brien to use non-local ingredients. It was common for Canadian brewers to import hops from Washington, California, and Idaho, and O'Brien reported that he would get his malt and hops from "the California metropolis [San Francisco]." 
Aside from hops and malt, there were other ingredients O'Brien required that did not grow in the Subarctic climate. For example, according to an 1899 recipe for ginger beer, O'Brien would have needed to import ginger root (possibly from Jamaica), lemons, and a special brewer's yeast. ${ }^{48}$ Beyond ingredients, the brewer O'Brien employed was an expert from San Francisco who used the infamous California method of making steam beer using the specific technique of kräusening, which is to put top-fermenting beers through a second fermentation process meant to speed up and add carbonation to beer. ${ }^{49}$ Burley and Will argue that "The types of beer and other commodities that were produced [at the brewery], the machinery by which they were produced, and the means by which they were packaged and marketed articulate the brewery with the outside world." ${ }^{50}$ At the same time, they reflect local conditions, challenges, and consumer demands that tied Dawson with southern Canada and the Lower 48.

Dawson and the rest of the Yukon maintained strong connections with the Outside (beyond the territory) since the beginning of the gold rush; not only did most people who came to the Klondike during the gold rush come from all over the world, but they brought with them southern ideologies, institutions, and structures. ${ }^{51}$ Newcomers who came to Dawson, like to settlements elsewhere in Canada, made concerted efforts to reproduce their older home communities in the Klondike. ${ }^{52}$ Not only did they maintain ideological connections with the Outside, but material ones as well-people had luxury items, such as silk stockings and pianos, shipped to Dawson. ${ }^{53}$ Although they had access to local meat and fish, Dawsonites also imported livestock not present in the Yukon, such as cows and chickens, in an attempt to replicate southern diets. Therefore, importing ingredients for beer was not unusual, especially given that the climate of the Yukon did not allow for local sourcing of the required ingredients-with the exception of water. What is interesting, however, was that O'Brien continued to promote his beer as "homegrown" despite the reliance on Outside ingredients.

Though the beer was clearly not crafted from local ingredients, that fact did not deter O'Brien from advertising his beer as homegrown-it was brewed in Dawson at a local facility, which seemed to matter more to the idea of locally produced than the origin of the ingredients. The Klondike Brewery offered a local option that came directly from the town rather than imported from Outside. They had local labels and a brand that stood 
behind place and community. ${ }^{54}$ Throughout the tenure of the brewery's operation, O'Brien first, and then Joseph Segbers, who bought the business from O'Brien in 1915, continuously expressed to customers that buying Klondike beer meant supporting local business and keeping money in the Yukon (see Figure 2). ${ }^{55}$

Beyond the practical and material elements that connected Dawsonites to Klondike beer, were important cultural elements. In his discussion of neo-localism Eberts argues that, "brands are used to convey multiple layers of meaning or values, and this can include an appeal to consumers' sense of identity. For many, this identity is inextricably tied to place." ${ }^{\prime 6}$ Through implementing typical "Klondike" imagery in their ads, the Klondike Brewery took advantage of the place-based identity present in Dawson by connecting its emphasis on locally produced beer with a sense of unique local culture.

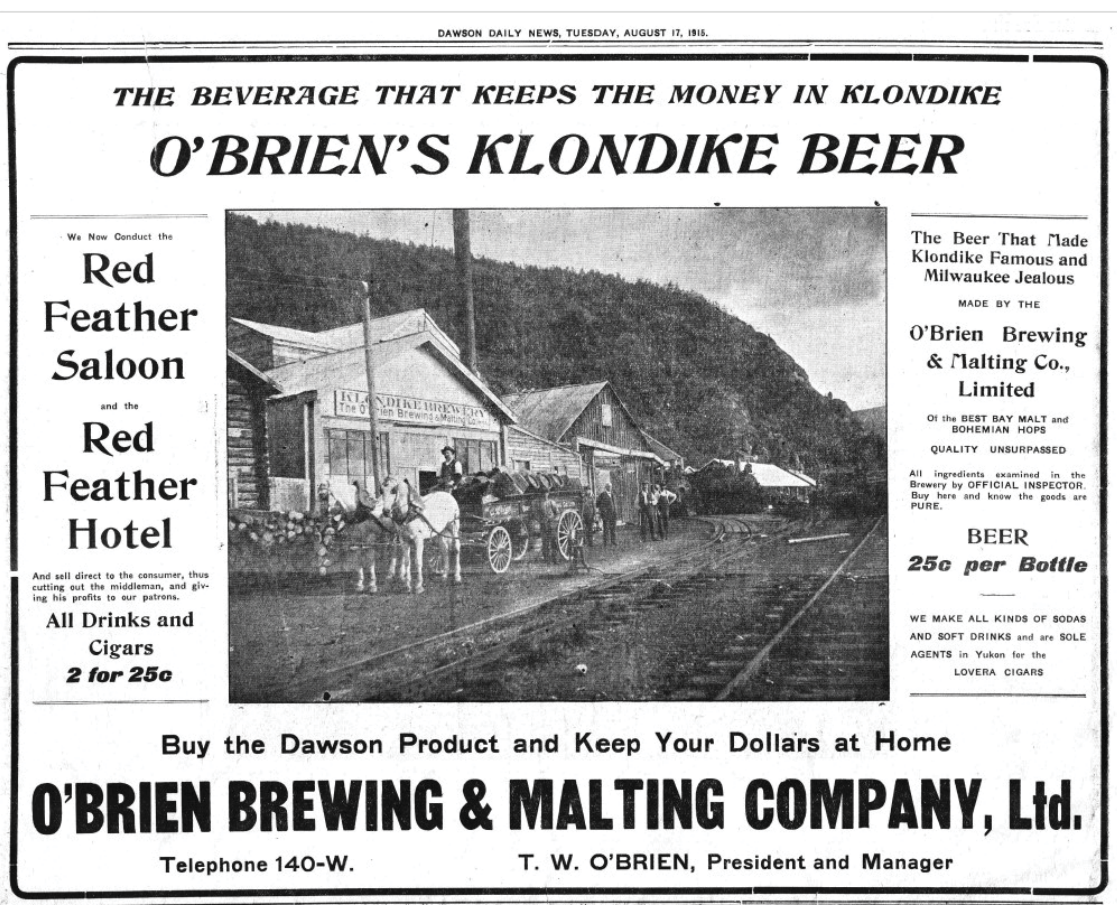

Figure 2.A commonly published advertisement for the O'Brien Brewing and Malting Company. Dawson Daily News, August 17, 1915. 
In his examination of beer commercials and masculinity, media ecology specialist Lance Strate identifies several techniques in modern beer advertising that utilize nature and extreme conditions, as well as leisure after a hard day of work, in order to appeal to a male audience. ${ }^{57}$ These techniques of emphasizing human connection with nature are also present in O'Brien's Klondike Brewery ads meant to appeal to Dawson's male population. The brewery itself was often called Klondike Brewery in ads, not its official name of O'Brien Brewing and Malting Co. This was a purposeful choice that appealed to the connection between place and identity in the Klondike. The image of the Klondike as a remote land with a harsh and extreme climate that "man" had to overcome was common in contemporary writing about the Yukon. Many people who spent time in the Yukon and who wrote memoirs or reported on their time there, often characterized the environment of the North as an untamed wilderness and an enemy that "man" had to fight, resist, and conquer in order to be successful in the Klondike. ${ }^{58}$

As mentioned earlier, the image of the Klondike, historically, was that of a very masculine space. Much of this was rooted in reality, with the population of Dawson during the years of the Gold Rush made up of ninety-two percent male to eight percent female in $1898 .^{59}$ Historians have examined a trend across North America at the turn of the twentieth century, which encouraged men to seek connections with nature and escape the confines and limitations placed on them by modern, industrial life. In her environmental history of the Klondike gold rush, Kathryn Morse argues that industrialization led to a feeling of human alienation from nature, but those who participated in the gold rush stepped away from the industrial world in the Yukon and came to rely on direct relations with the natural world.$^{60}$ The idea of the Klondike offering a pre-industrial way of living and labour attracted many Americans to the gold rush as they sought an escape from the boredom of industrialized life and society. Historians Tina Loo and Tina Adcock have each examined the belief, held in the late nineteenth century, that the modern world was making men effeminate, and that engaging with nature was an ideal way to restore masculinity. ${ }^{61}$ In 1898, American novelist and essayist Hamlin Garland, who visited Dawson, explained in a McClure's Magazine article that the type of man who could reap the benefits of the Klondike's wealth was, "a man enlisting for a war. He should be able to pass the examination which 
is required of a soldier in the German army. [...] It is no place for weak men, lazy men, or cowards." 62

This idea of the Klondike strengthening the relationship between "man" and nature was strongly tied to concepts of the working man and frontiersman. Between 1896 and 1900, semi-skilled and unskilled workers made up sixty-five percent of Dawson's workforce, over half of whom were miners. Even after the gold rush, the majority of workers in Dawson were semi-skilled tradesmen. ${ }^{63}$ Appealing to the working class in Dawson made good business sense for O'Brien. Many of his ads directly appealed to the labourers in Dawson, while also connecting to the Klondike's specific local environment. For example, in May of 1905 one ad in the Dawson Daily Nerws specifically referenced the harsh winters (see Figure 3).

The Klondike winter was no easy place to live and work, and this ad suggests that surviving a gruelling winter should mean rewarding oneself with a beer. Further, this ad worked doubly to appeal to workers who were about to the endure a season of physical labour and heat, and a big glass of refreshing beer-such as a lager or a steam beer-after work would indulge a worker's thirst.

The idea of the Yukon as a working man's space correlated with the concept of frontier masculinity in the late nineteenth and early twentieth centuries. Characteristics of frontier masculinity were quite similar across the British Empire. Historian Angela Woolacott examined frontier masculinity in the Australian context, and Adele Perry and Elizabeth Furniss have both studied the gendered aspects of resource extraction

\section{BEER SEASON NOW OPEN!}

The warm weather is surely with 'us and the thirsty cry for

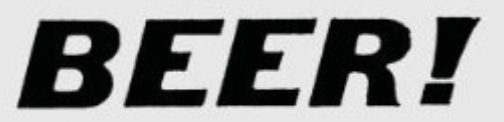

The Klondike Brewery's Steam and' Lager'I

Beer (big glasses) reaches the spot as no other beer can.

CALL FOR THE BIG STEAM OR THE BIG I.AGERI

Figure 3. A Klondike Brewery advertisement. Dawson Daily News, May 25, 1905. 
in frontier zones in British Columbia. These studies have shown that across the empire, frontier masculinity was characterized by freedom and independence from the constraints of modern life; bravery and courage; knowledge of the natural world and physical and mental ability to conquer nature; sportsmanship; resilience; individualism; and a willingness to engage in violence if, or when, necessary. Expressions of frontier masculinity also included the assertion of dominance not only over local environments, but over women and local Indigenous populations. ${ }^{64}$ The concept of frontier masculinity in the Yukon shared these characteristics, but also included localized traits. Historians Peter Kikkert and Whitney Lackenbauer have analyzed these beliefs about frontier masculinity in their work on Yukon soldiers in the First World War, with a thorough analysis of editorials and published soldiers' letters in the Dawson Daily Nerws, which often proudly remarked on the masculine characteristics of Yukon soldiers. ${ }^{65}$ These editorials suggest that men from the Yukon were more self-reliant, could more easily physically and mentally adapt to challenging environments, and were more innovative in difficult circumstances than men from elsewhere in Canada. ${ }^{66}$

In the Yukon, the ultimate frontiersmen were the Yukon pioneer and the sourdough. The sourdough-a term that described an experienced gold miner or a southerner who became a long-time resident of the North-was a crucial image to the unique local culture of the Klondike. The sourdough was a true Yukoner, one who was there before the rush-the term could also create a sense of pride among those who stayed after the rush to settle and call the Yukon home. Even as mining in the Yukon shifted from that of placer mining to industrial dredging, the image of the individualistic and independent sourdough remained the stereotypical image of Yukon masculinity decades after the gold rush ended. Figure 4 portrays a typical mining scene around the Klondike goldfields-as the original caption suggests, these men fit the ideal image of the Yukon sourdough.

O'Brien called upon the image of the sourdough in marketing his brewery. The most obvious of these ads was one that O'Brien ran annually between 1912 and 1917 that had a bold headline exclaiming that his beer was "The Sourdough's Favorite Beverage." ${ }^{77}$ As the population declined, O'Brien devoted more newspaper space stressing the permanency of his business. He also printed ads targeted specifically at members of the Yukon Order of Pioneers (Y.O.O.P.)—a fraternal club for men who had resided 
in the Yukon, "in good standing," for at least ten years. ${ }^{68}$ In using terms like "sourdough," and demonstrating connections to Y.O.O.P., he attempted to appeal to the loyalty of those who remained after the gold rush.

O'Brien's personal reputation also helped strengthen the branding of the brewery as a pioneering venture. O'Brien was a well-known and respected Dawsonite. He was a sourdough himself and an early Yukon entrepreneur. ${ }^{69} \mathrm{He}$ arrived in Forty Mile, north of what would become Dawson, in 1887 and worked as a trader and prospector eventually opening a store with his partner, Billy Moran. O'Brien was among the first "rush" into the Klondike in 1896, and a year later he and Moran built a warehouse and store in Klondike City where he owned many properties and other businesses as discussed earlier.

Despite his sourdough status, O'Brien was not popular with Dawson miners. O'Brien's Pioneer Tramway, which took passengers and freight to the goldfields, became controversial in 1898, especially among miners, when he set up toll collectors and charged passengers per ride as well as increasing freight costs to ten cents per pound. ${ }^{70}$ O'Brien shortly after gave up maintaining the tramway and took over a footbridge to the goldfields in 1901, announcing that the bridge would remain open for free passage. In 1902 he began charging a toll for crossing the bridge, to the great displeasure of Klondike miners. ${ }^{71}$

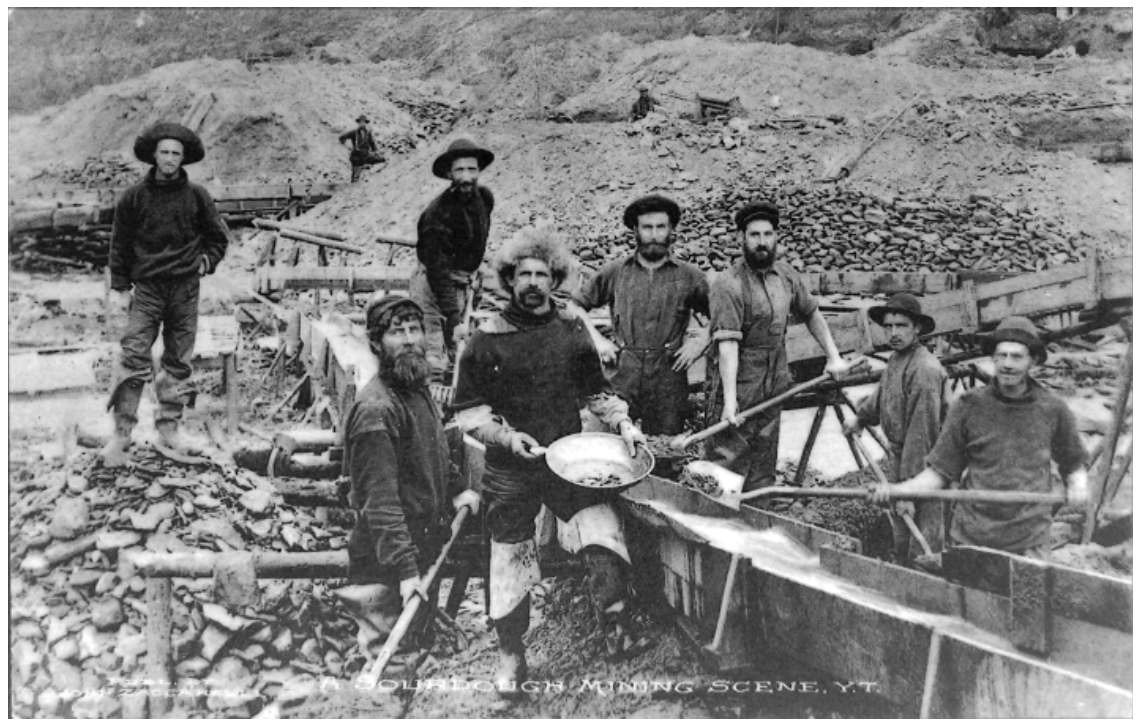

Figure 4. A group of "sourdoughs" in the gold fields, c I900. DCMA 1994.279.66. 
Regardless of O'Brien's relationships with miners, he firmly established himself in the social fabric of the Klondike. Beside his economic activities, he bought the Yukon Sun newspaper in 1900, served as president (19051907) and active member of Y.O.O.P. throughout his life, worked in local politics by serving on the Yukon Council as Counsellor for South Dawson from 1905-1906, and as the leader of the Liberal Party from 1905-1907. $\mathrm{He}$ also owned the Dominion Hotel in Dawson and the Red Feather Saloon. By 1911, O'Brien was still politically active, though he represented the Conservatives in the election that year. ${ }^{72}$ Unlike many others who came into the Klondike at the turn of the century, he made his fortune in the Yukon and remained, making it his home until his death. ${ }^{73}$

His involvement in various business ventures and politics proved he was a committed Yukoner who worked to develop the region. He was so popular in town that in 1902 Dawson citizens began a petition to persuade O'Brien to allow his nomination for Yukon Council. Within two hours it had gained hundreds of signatures from Dawsonites. They applauded his "loyalty to everything that would advance the best interests of this country." 74 Before the brewery opened, the Yukon World reported on the brewery and stated that O'Brien, "has always been on the frontier all his life. There is no more typical pioneer than Mr. O'Brien." 75 When O'Brien died on August 24, 1916, ironically from liver trouble, notice of his death occupied full front-page news in the local papers. The Dawson Daily Nerws described O'Brien as a Yukon Pioneer and Empire Builder, and his funeral closed down Dawson businesses and government operations for the day out of respect and esteem. It was one of the largest attended funerals in the Yukon to that point with hundreds lining the streets and attending a parade procession. ${ }^{76}$ The combination of O'Brien's notoriety and his ads championing Yukon pride worked to secure a certain image of his beer and his customers. There is no doubt that Tom O'Brien felt a sense of attachment to the Klondike and a large part of his individual and community identity was tied to place. O'Brien had great pride in being a Yukoner and believed that those who remained after the gold rush felt similarly. Capturing nostalgia about the pioneering days at the turn of the century in his advertising was important to sense of place and the culture of the Klondike.

But O'Brien was not stuck in the past; his ads and the way he ran his brewery also expressed his commitment to "modernizing" the Klondike. ${ }^{77}$ 
Even before the brewery opened, the Yukon Sun boasted it would be the "most extensive brewing plant in the North." 78 The Klondike Brewery was the only brewery in the Yukon, but Alaska boasted several breweries that may have taken umbrage with O'Brien's claims, including the Tanana Brewing Co., Barthel, and Arctic Brewing in Fairbanks; Nome Brewing Co., Skagway Brewery, and Eagle Brewery in Skagway; Valdez Brewing Co. and a host of breweries in Douglas City and Juneau, Alaska. ${ }^{79}$ Despite these Alaskan options, O'Brien expected the market to extend beyond Dawson, though it never did.

O'Brien and his team, including master-brewer Charles E. Bolbrugge from San Francisco, attempted to place the Klondike Brewery on a global scale by connecting his modern operation, modelled on San Francisco breweries, with the growth of technological transformation in brewing more broadly. This was particularly evident in his decision to adopt the Steam Beer technique. The choice to use the steam beer technique was both technologically and culturally significant. Steam beer is a style still familiar today in California, now called California common beer. This distinct technique was created for the hot temperatures associated with brewing beer in California and west coast breweries that had trouble acquiring ice for low temperature fermentation. Utilizing both German lager technique and yeast, Californian brewers developed a method by which steam power was used to ferment lager yeast at higher temperatures in shallow open-air fermenters. Fermentation resulted in flat beer, so brewers carbonated through a second fermentation, or "krausening," in a colder environment, to remove any unwanted flavours associated with brewing at high temperatures, and which led to strong carbonation that gave the appearance of a release of steam when the keg was tapped, creating a heady top foam. ${ }^{80}$

Krausening was not required to make clean-tasting beer in Dawson where the temperatures are far colder than in California. O'Brien's decision to produce steam beer from his brewery-bringing in the equipment to create steam beer and hiring a Californian brewer who was experienced in the krausening process-was a purposeful action either to associate the Klondike Brewery with technological achievements in brewing, and support his claim of building the "most extensive brewing plant in the North," or because this beer style was meant for specific consumers in Dawson City. ${ }^{81}$ 
O'Brien's choice to produce a steam beer in Dawson could have reflected his consumer base, or at least who he believed his consumer was. Steam beer was simultaneously an endemic American style born from the needs of beer consumers and reactionary to the specific needs of the hot Californian environment. However, contemporary brewing manuals as well as popular literature from this time suggests that steam beer was more than the quintessential Californian beer, but was also the quintessential beer of the working classes. Wahl and Heinus's American Handy Book of the Brewing Malting and Auxiliary Trades, published in 1902, describes steam beer as "a very clear, refreshing drink, much consumed by the labouring classes." 82 Author Jack London, who spent time in Dawson during the gold rush, also alluded to steam beer's working-class roots in his memoir John Barleycorn. ${ }^{83}$

In using the name Klondike Brewery in his advertisements and news articles, as well as advertising the brewery's connection with California ingredients, O'Brien was purposefully aligning his brewery with the bustle and wealth of gold-rush-era Dawson City and with his own notoriety as a sourdough and pioneer in the Klondike, in an appeal to his male customers.

However, there is also evidence that O'Brien was cognizant of a possible female customer base as well. Historical studies of alcohol and beer from the nineteenth and early twentieth centuries generally focus on men, as public drinking was identified as more of a masculine activity. In Dawson, women did not shy away from the drinking culture and social life of the town, however it was more common for prostitutes and other "unrespectable" women to be open about alcohol consumption. Figure 5 shows a group of prostitutes posing for a photo at their "drinking bee" in 1900. There is evidence that suggests O'Brien also appealed to women in his ads, specifically through the context of family and domestic life. For example, the ad in Figure 6, which mentions family, as well as home delivery, suggests that O'Brien recognized that the numbers of women and families were growing in Dawson and they offered a new customer base. As mentioned earlier, during the gold rush year, males made up between eighty-eight to ninety-two percent of Dawson's population. By 1921, that gender divide had decreased with sixty-eight percent men and thirty-two percent women. ${ }^{84}$ It seems likely that O'Brien was engaging with women through the woman's domain of household and family in this ad, which he produced again in future years. He further hoped to capture more customers 
through his non-alcoholic products. This is indicated in ads that mention soft drinks and, in addition, by 1914 the brewery made home deliveries. ${ }^{85}$ This was likely in reaction to a developing temperance movement in Dawson, similarly to elsewhere in Canada at this time, largely supported by women. By advertising both alcoholic and non-alcoholic products to different audiences in Dawson City, O'Brien attempted to garner a solid customer base in a former gold rush town where the future growth of the town and population was uncertain.

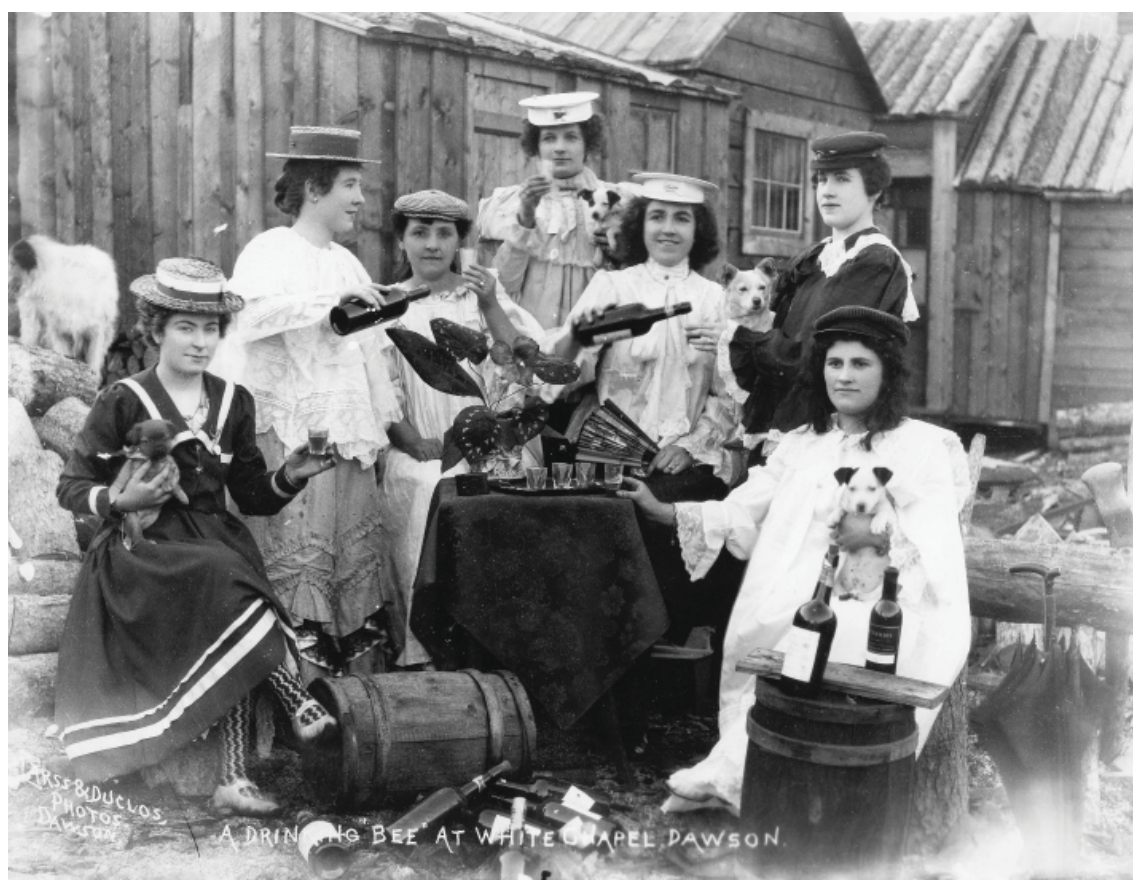

Figure 5. A "Drinking Bee" at White Chapel, Dawson, I900. DCMA 20I I.I4.37. 
News coverage and ads for the Klondike Brewery in the Yukon Sun and the Dawson Daily News make clear O'Brien's attempt to create customer loyalty by appealing to place-based identity and local culture though reinforcing the established idea of the Yukon pioneer while also emphasizing the modernization and permanency of Dawson. Connected to these ideas were ads that emphasized the health benefits of drinking Klondike beer. During a period when ill-health became increasingly monitored in Dawson, O'Brien emphasized that his beer was a healthy, local alternative to imported goods. After 1913 especially, Klondike Brewery ads emphasized the health benefits of drinking their beer. An ad that ran on December 9, 1913, in the Dawson Daily News (Figure 7) encouraged its readers to "Hear the Doctor," arguing a certain amount of alcohol was necessary for digestion and to ensure a healthy stomach. A 1914 ad stated Klondike Brewery products were "free from injurious chemicals, are health producing, and no family should be without it," where another simply stated, "For Good Health Drink O'Brien Brewing and Malting Co.'s Beer." 86

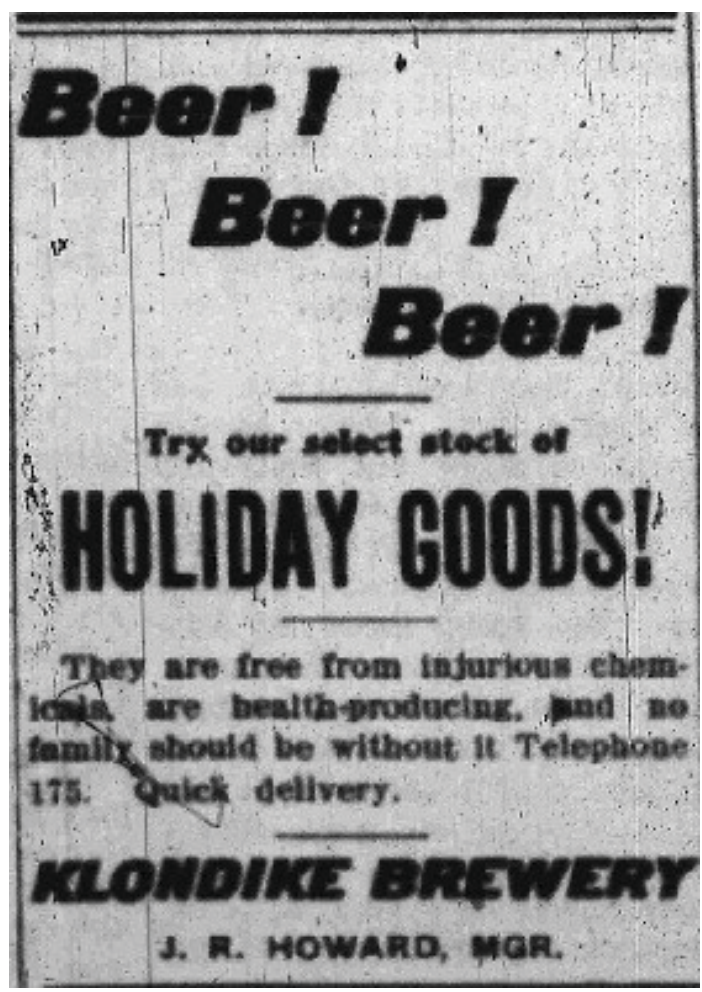

Figure 6. Holiday beer ad. Dawson Daily News, October 24, 1914. 
It is possible that this "healthful" ad campaign was a response to the developing temperance movement in Dawson that saw liquor as a social ill, as Burley and Will suggest. ${ }^{87} \mathrm{It}$ is more likely, however, that this campaign was a response to local health and sanitation conditions in Dawson City ${ }^{88}$ Though the population in Dawson expanded between 1896 and 1899, sanitation services did not arrive with increased numbers of people and Dawson was left with poor sanitation that created health hazards for everyone living in the area. The Yukon River was used as a garbage disposal due to the lack of disposal facilities in Dawson. Sewage was also dumped into both the Klondike and Yukon rivers, which resulted in health hazards and the contamination of the water supply. Instances of typhoid, dysentery, and diarrhea ran rampant in Dawson in the early 1900s. After tuberculosis outbreaks between 1907 and 1910, settlers seemed increasingly preoccupied with hygiene and sanitation. Anglican ministers began giving lectures in churches and Indigenous communities about health, hygiene, and sanitation and, after this time, there was more local media coverage about health. ${ }^{89}$ It was not until the 1930s that Dawson had a proper (and regularly functioning) drainage system. Dr. Alfred Thompson, a respected doctor in town and known friend of Thomas O'Brien, was part owner of O'Brien Brewing and Malting Co., and it is possible that his association with the Brewery gave more weight to these types of ads.

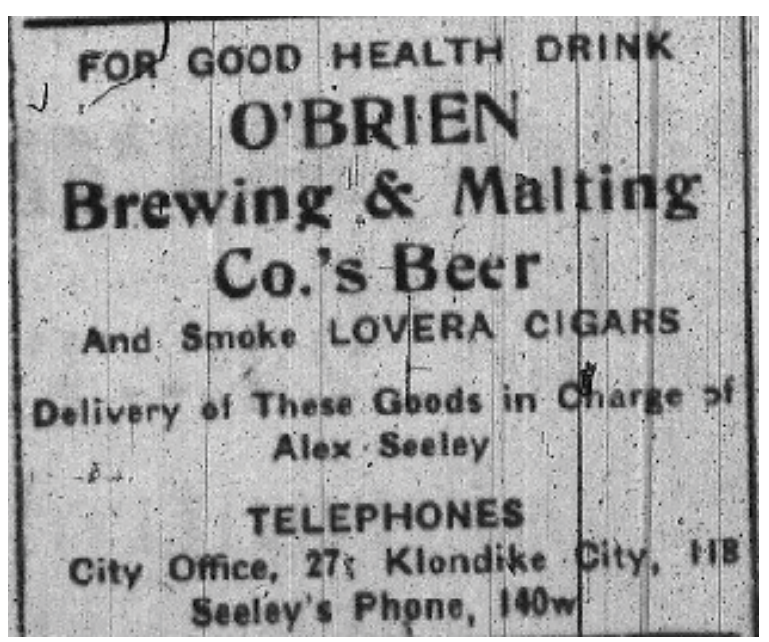

Figure 7.A Klondike Brewery ad espousing good health. Dawson Daily News, December 9, 1913. 
O'Brien advertised widely between 1904 and 1915 for his "Yukon made" lager, a style of beer that had gained popularity in North America in the nineteenth century. Historian Jeffrey Pilcher argues that aside from price, what made lager rise in global popularity was that it seemed to express ideals of modernity. It had a clean, hygienic taste that stood in contrast to heavier, strongly flavoured beers, which often had bacterial contamination. $^{90}$ Bacterial contamination was certainly a concern in Dawson during the lifespan of the Klondike Brewery. As discussed above, the only local ingredient used in Klondike beer was water. The water used by the brewery came from the same water supply-the local rivers - that previously had helped spread typhoid, diarrhea, and dysentery. Contaminated water was also an effect of mining activity. For example, arsenic was natural to the environment of Dawson but was disturbed with mining, exposing arsenic-containing rocks to surface water and eventually into the water supply. Historian Liza Piper argues that placer mining employed relatively few chemicals with the exception of mercury, which resulted in mercury-contaminated water descending into the tailing piles, and into the ground and surrounding waters of the Klondike River and creeks. $^{91}$

A critical improvement to hygiene and sanitation in Dawson was the construction of drainage and sewer systems with provision for a clean water supply. There was a newly formed Board of Health in 1899 and by 1900 , before the opening of the brewery, adequate sewer and water supply systems operated. ${ }^{92}$ However, because local health conditions during the gold rush could often be traced back to polluted water supplies, it is possible that people may have been hesitant to drink beer produced with local water at first. O'Brien's ads emphasizing how modern the brewery was, and the healthy quality of the beer and the water it used, was perhaps an effort to quell any concern that the water was still unhealthy.

The Klondike Brewery ceased operation in 1919 when the Yukon Territorial Government passed prohibition legislation. But even before prohibition, the brewery suffered a downturn in sales, as well as decreased production beginning in 1914. Much of this decline in activity in the last five years of the brewery's lifespan was a result of the First World War. According to historian Michael Gates, nearly a quarter of the Yukon's population, 
or over 900 men, enlisted in the war leading to a tremendous population fluctuation during the war years. ${ }^{93}$ This lower population of men in the Yukon likely had consequences for the Klondike Brewery. Furthermore, the war helped bolster the efforts of prohibition groups that had been at work all across Canada in the early twentieth century. In the Yukon, women's groups and patriotic societies in particular vocally campaigned for prohibition throughout the war years, arguing that money spent on alcohol consumption and production would be better spent on the war effort. While prohibition was a popular cause in the Yukon, a plebiscite on the issue in August of 1916 resulted in a win for the "Wets" by only three votes. ${ }^{94}$ Finally, the war led to economic decline in the Yukon as well. During war years, the gold standard decreased in value, and the war-related rise in production costs was not sustainable for large mining corporations to produce at the same capacity they had prior to war. Additionally, other minerals used in wartime production, such as copper and silver, were in greater demand than gold—and gold was the staple of the Yukon's economy. ${ }^{95}$ This economic decline was particularly dramatic considering the rapid industrialization of gold mining in the territory less than a decade earlier. ${ }^{96}$ By 1914 , a reduced population, the push for prohibition, and economic decline together undoubtedly impacted beer sales in the Klondike.

Though the brewery operated only fifteen years, the O'Brien Brewing and Malting Company was one of the longest-lasting and more successful post-gold-rush businesses in the Yukon. Once the Klondike Brewery closed, the Yukon remained without a brewery until 1997 when Yukon Brewing opened in Whitehorse. Alcohol and saloons have been included, at least in some capacity, in nearly every historical study of the Klondike gold rush. Drinking was clearly an informative aspect in the unique culture and local identity of miners, but the importance of alcohol and venues for its consumption did not fade out after the rush. Though the population of Dawson declined rapidly following the gold rush, a population remained and restructured their sense of community, culture, and identity to adapt to these new circumstances.

Thomas O’Brien's marketing of Klondike Brewery beer to the postgold-rush settler population drew on the interconnected web of place, history, and identity. He emphasized the "Yukon-ness" of his products by advertising them as locally based, appealing to historic images and a unique 
local culture, and interacting with the possibilities of Dawson's future. His approach to gaining customers suggests that the strategy of neo-localism is not a recent concept developed by craft brewers in the 1980s, but an older tradition that attempted to connect people to the products they consumed.

Little evidence exists that allows us to analyze the reception of these ads, and that of the brewery itself, among the Dawson population, though some sources allow us to draw some likely conclusions. The amount of coverage the Dawson Daily Nerws — not owned by O'Brien-afforded to the brewery throughout its construction and lifespan suggests that there was some level of excitement for this new addition to local industry, and hope for continued development in Dawson. ${ }^{97}$ What we are more certain of is that both the ads and O'Brien's brewery provide a glimpse into the way that he perceived post-gold-rush culture and identity, and the future he believed Dawson could have. He perceived Dawson as a permanent community, with settled families, building a modern (and healthy) future for itself. This cultural identity related to both past and present.

Whether it was advertising the Klondike Brewery through an emphasis on supporting local business, the modernity of the brewery itself, an appeal to a broad audience, or through the health benefits of a cold beer, Thomas O'Brien attempted to make his business a success through connecting it to the vision he had for Dawson's future. The life of Thomas O'Brien and the Klondike Brewery was intimately tied to the life of Dawson City. O'Brien was a sourdough and pioneer, yet he was also a modernizing force in Dawson City when Dawson was defining itself after the gold rush. The Klondike Brewery hearkened to the glory days of the gold rush in Dawson, but also represented a hope for permanency and growth. The Klondike Brewery, as a cultural institution for a period of time in Dawson City, is a window through which we can view Dawson City after the gold rush. While we will never know the taste of the beer that would "make Milwaukee Jealous," we can get a glimpse of Dawson through the lens of O'Brien's brewery.

\section{Notes}

1. Derreck Eberts, "Neolocalism and the Branding and Marketing of Place by Canadian Microbreweries," in The Geography of Beer: Regions, Environment, and Societies, ed. Mark Patterson and Nancy Hoalst-Pullen (Kennesaw: Springer, 2014), 190. The term "neo-localism" was coined by geographer 
Pete Shortridge in 1996. Steven M. Schnell, John Patrick Harty, and L. Scott Deaner, "You gotta know the territory': The work of James"Pete" Shortridge (thus far)," Journal of Cultural Geography 30, 1 (2013): 1-5.

2. Mary Douglas, "A Distinctive Anthropological Perspective," in Constructive Drinking: Perspectives on Drink from Anthropology, ed. Mary Douglas (Cambridge: Cambridge University Press, 1987), 8.

3. Lael Morgan, Good Time Girls of the Alaska-Yukon Gold Rush (Vancouver: Whitecap Books, 1999), 28.

4. David Burley and Michael Will, Special Brew: Industrial Archaeology and History of the Klondike Brewery, Occasional Papers in Archaeology No. 11 (Whitehorse: Government of Yukon, 2002); David Burley and Michael Will, "The Beer That Made the Klondike Famous and Milwaukee Jealous": The O'Brien Brewing and Malting Company Site, Klondike City, Yukon," The Journal of the Society for Industrial Archaeology 26, no. 1 (2000): 37-54.

5. Burley and Will, Special Brew, 19.

6. Many scholars have commented on these entrepreneurs who went to "mine the miners" including Pierre Berton, The Last Great Gold Rush, 1896-1899 (Toronto: Anchor Canada, 1972); Charlene Porsild, Gamblers and Dreamers: Women, Men, and Community in the Klondike (Vancouver: UBC Press, 1998); and Charlotte Gray, Gold Diggers: Striking It Rich in the Klondike (Berkeley: Counterpoint, 2010).

7. Margaret Archibald, "Grubstake to Grocery Store: Supplying the Klondike, 1897-1907," in Canadian Historic Sites: Occasional Papers in Archaeology and History (Ottawa: Parks Canada, 1981), 35.

8. Max Nelson, The Barbarian's Beverage: A History of Beer in Ancient Europe (London: Routledge, 2005), 11.

9. Richard Stuart, Dawson City: Three Structural Histories (Ottawa: Parks Canada, 1980), 13. Charlene Porsild discusses the demographics of Dawson during the Gold Rush in Gamblers and Dreamers (1998).

10. Such studies include Craig Heron's Booze: A Distilled History (Toronto: Between the Lines, 2003); Peter DeLottinville, "Joe Beef of Montreal: Working-Class Culture and the Tavern, 1869-1889," Labour/Le Travail 8/9 (Autumn 1981-Spring 1982): 9-40; Julia Roberts, In Mixed Company: Taverns and Public Life in Upper Canada (Vancouver: UBC, 2009).

11. Amy Mittelman, Brewing Battles: A History of American Beer (New York: Algora Publishing, 2009), 48.

12. Some works that discuss the Yukon as a frontier include Charlotte Gray, Gold Diggers (2010); Jim Wallace, Forty Mile to Bonanza: The North-West Mounted Police in the Klondike Gold Rush (Calgary: Bunker to Bunker Publishing, 2000); Charlene Porsild, Gamblers and Dreamers (1998); Francis 
Backhouse, Women of the Klondike (Vancouver: Whitecap, 1995); Melanie Mayer, Klondike Women: True Tales of the 1897-1898 Gold Rush (Ohio University Press, 1989); William Morrison, Showing the Flag: The Mounted Police and Canadian Sovereignty in the North, 1894-1925 (Vancouver: UBC Press, 1985); William Hunt, North of 53: The Wild Days of the Alaska-Yukon Mining Frontier, 1870-1914 (Fairbanks: University of Alaska Press, 1974); Pierre Berton, The Last Great Gold Rush (1972); Harold Innis, "Settlement and the Mining Frontier," in Canadian Frontiers of Settlement v. 9. (Toronto: Macmillan, 1936).

13. Porsild, Gamblers and Dreamers, 173.

14. Margaret Carter, “O’Brien Brewing and Malting Company, Ltd.," in Society for Industrial Archaeology Study Tour of the Yukon and Alaska, ed. Ken Elder (Ottawa: Society for Industrial Archaeology, 1990), Entry 38.

15. Eric L. Johnson, The Bonanza Narrow Gauge Railway: The Story of the Klondike Mines Railway (Vancouver: Rusty Spike Publishing, 1997), 29.

16. Roberts, In Mixed Company, 101.

17. Johnson, 2-3.

18. Johnson, 102-103.

19. Shelley Gavigan, Hunger, Horses, and Government Men: Criminal Law on the Aboriginal Plains (Vancouver: UBC Press, 2012), 132.

20. The consumption of alcohol among Indigenous peoples in the Yukon occupied the attention of White settlers since the 1870s. By 1894, for example, the town of Forty Mile- a small mining town north of Dawsonhad ten saloons and several distilleries that caused great anxiety among Anglican Bishop William Carpenter Bompas. He undertook a campaign writing letters to the Dominion government beginning in 1893 requesting police presence in the Yukon to monitor and enforce the rules of the Indian Act. The North-West Mounted Police invested much effort in pursuing people accused of distributing liquor to Indigenous peoples in the Dawson area and punished both those Indigenous peoples they discovered under the influence of alcohol as well as those who supplied the liquor, if known. Yukon Archives, Bishop Bompas fonds (81/83) MSS 125; NWMP, Report of Inspector Starnes (Northwest Mounted Police Annual Report, December 1901); NWMP, Report of Commissioner A. Bowen Perry (Northwest Mounted Police Annual Report, 1908); Report of Commissioner A. Bowen Perry (Northwest Mounted Police Annual Report, November, 1911); Report of Superintendent Major Moodie (Northwest Mounted Police Annual Report, November, 1913). 
21. Developmental Studies Program, Moosehide: An Oral History (Dawson: Yukon College, 1994), 36. Enfranchisement is the act of legally giving up one's Indian Status.

22. Robert Campbell, Sit Down and Drink Your Beer: Regulating Vancouver's Beer Parlours, 1925-1954 (Toronto: University of Toronto Press, 2001); Dan Malleck, Try to Control Yourself: The Regulation of Public Drinking In Post-Prohibition Ontario, 1927-44 (Vancouver: UBC Press, 2012); Robert Campbell, "Making Sober Citizens: The Legacy of Indigenous Alcohol Regulation in Canada, 1777-1985," in Journal of Canadian Studies 42,1 (Winter 2008): 105-126.

23. Stuart, Dawson City, 35.

24. Dawson City Museum Archives, "Klondike Brewery."

25. Carter, Entry 38.

26. In the April 1915 session of the Yukon Council the Women's Christian Temperance Union presented a petition to reduce the number of licensed premises in Dawson. Stuart, Dawson City, 39, 45.

27. Stuart, Darwson City, 40.

28. Stuart, Dawson City, 21.

29. There is no population data for the Yukon prior to 1898. The only available data for Dawson City specifically comes from an 1898 and a 1900 census compiled by the North-West Mounted Police (NWMP). After this time, the only available population numbers include the entirety of the Yukon Territory. The NWMP completed the first Yukon Census in 1898, where they estimated a total population of 40,000 people in the Klondike region, 15,203 of which were living in Dawson City. Porsild, Gamblers and Dreamers, 203-205. According to the Dawson Daily Nerws, citing NWMP data, there were 5,404 people living in Dawson as of May 1900. Darwson Daily Nerws, May 2, 1900. Population numbers for the Yukon from 1901 to 1951 found in Statistics Canada, Census of Canada, 1951, vol. X, table 1.

30. Stuart, Dawson City, 35.

31. "Act Upon Memorial for Beer," Yukon Morning World, October 1, 1908.

32. Sally Robinson, "The Home Front: The Yukon's Economy During the First World War," The Northern Review 44 (2017): 32.

33. Dawson City Museum Archive, "O’Brien, Thomas and Annie."

34. Burley and Will, Special Brew, 12-13.

35. Klondike City refers to the section of land across the Klondike River from the north side of Dawson City.

36. "Home Grown Steam Beer," Yukon Sun, January 21, 1904 and "Brewery Nearly Ready to Brew," Yukon Sun, February 19, 1904.

37. "Brewery Nearly Ready to Brew," Yukon Sun, February 19, 1904. 
38. Ibid. At its peak production, the Klondike Brewery produced 68,000 gallons for the year in 1906.

39. "Brewery Nearly Ready to Brew," Yukon Sun, February 19, 1904. Burley and Will make a similar observation in Special Brew, 16.

40. Stuart, Dawson City, 35. The category of imported beer also included beer shipped into Dawson from southern Canada. Margaret Archibald, "Grubstake to Grocery Store," 112.

41. "The Beverage that keeps the Money in Klondike," Dawson Daily News, August 11, 1915.

42. Burley and Will, Special Brew, 40-41.

43. Burley and Will, Special Brew, 1.

44. "Home Grown Steam Beer," Yukon Sun, January 21, 1904.

45. "Hop Distillery Nearly Finished," Yukon Sun, January 29, 1904; "Brewery Nearly Ready to Brew," Yukon Sun, February 19, 1904.

46. Jay Gatrell, David Nemeth and Charles Yeager, "Sweetwater, Mountain Springs, and Great Lakes: A Hydro-Geography of Beer Brands" in The Geography of Beer: Regions, Environment, and Societies. Mark Patterson and Nancy Hoalst-Pullen, ed. (Kennesaw: Springer, 2014): 89-90.

47. "Hop Distillery Nearly Finished," Yukon Sun, January 29, 1904; "Brewery Nearly Ready to Brew," Yukon Sun, February 19, 1904; "Big Slash in Beer," Darwson Daily Nerws, August 9, 1913.

48. Donald Yates, "Ginger Beer and Root Beer Heritage," in Bottles and Extras (Spring 2003): 14

49. "Brewery Nearly Ready to Brew," Yukon Sun, February 19, 1904. The kräusening technique was "entirely American in origin." N. Van Laer, "The Chilling Filtering of Top-Fermenting Beers, Part II," Journal of the Federating Institutes of Brewing IX (1903): 65.

50. Burley and Will, Special Brew, 8.

51. Morris Zaslow, The Opening of the Canadian North, 1870-1914, The Canadian Centenary Series (Toronto: McClelland and Stewart, 1971); Ken Coates, "Asking for All Sorts of Favours: The Anglican Church, the Federal Government and the Natives of the Yukon Territory, 1891-1909," The Anglican Church and the World of Western Canada, 1820-1970, ed. Barry Ferguson (Regina: University of Regina, 1991): 126-142; Morrison, Showing the Flag.

52. Morris Zaslow discusses the reproduction of Victorian ideals in the Klondike in a comparative study of Canadian and American frontiers in "The Yukon: Northern Development in a Canadian-American Context," Interpreting Canada's North, ed. Ken Coates and William Morrison (Toronto: Copp Clark Pitman Ltd., 1989), 141. 
53. Porsild, Gamblers and Dreamers, 129.

54. O'Brien recycled existing bottles when bottling his beer. He had no problem using old bottles with his competitors' names embossed into the glass, as he counteracted this with labels to personalize his product. Burley and Will, Special Brew, 89.

55. "Big Slash in Beer," Dawson Daily Nerws, August 9,1913; “Keep the Money in the Klondike," Dawson Daily Nerws, August 9, 1917.

56. Eberts, "Neolocalism and the Branding," 192.

57. Lance Strate, "Beer Commercials: A Manual on Masculinity" in Men, Masculinity, and the Media, ed. Steve Craig (Thousand Oaks, CA: Sage Publications, Inc, 1992), 82.

58. Janice Cavell, "The Second Frontier: The North in English-Canadian Historical Writing," Canadian Historical Review 83, no. 3 (2002): 369.

59. Porsild, Gamblers and Dreamers, 208.

60. Kathryn Morse, The Nature of Gold: An Environmental History of the Klondike Gold Rush (Seattle: University of Washington Press, 2003), 12.

61. Tina Loo, "Of Moose and Men: Hunting for Masculinities in B.C., 18801939" in Western Historical Quarterly 32 (Autumn 2001): 29; Tina. Adcock, "Many Tiny Traces: Antimodernism and Northern Exploration Between Wars," in Ice Blink: Navigating Northern Environmental History, ed. Stephen Bocking and Brad Martin (Calgary: University of Calgary Press, 2016), 139-140. Gabrille Zezulka-Mailloux also discusses the rejuvenating aspects of "wilderness" at the turn of the twentieh century in Ian McLaren's edited collection examining parks as escapes from the strife of modern city life in "Laying the Tracks for Tourism: Paradoxical Promotions and the Development of Jasper National Park," in Culturing Wilderness in Jasper National Park: Studies in Two Centuries of Human History in the Upper Athabasca River Watershed, ed. Ian McLaren (Edmonton: University of Alberta Press, 2007): 245-47.

62. Hamlin Garland, "Ho, for the Klondike!" McClure's Magazine (March 1898): 454.

63. Porsild, Gamblers and Dreamers, 60, 292.

64. Angela Woolacott, "Frontier Violence and Settler Manhood," History Australia 6, no. 1 (2009): 11.1-11.15; Adele Perry, On the Edge of Empire: Gender, Race, and the Making of British Columbia, 1849-1871 (Toronto: UofT Press, 2001); Elizabeth Furniss, The Burden of History: Colonialism and the Frontier Myth in a Rural Canadian Community (Vancouver: UBC Press, 1999). Bradley Deane, Masculinity and the New Imperialism: Rewriting Manhood in British Popular Culture, 1870-1914 (Cambridge: Cambridge University Press, 2014) also analyzes frontier masculinity at this time. 
65. Peter Kikkert and P. Whitney Lackenbauer, “Men of Frontier Experience': Yukoners, Frontier Masculinity and the First World War," Northern Review 44 (Spring 2017): 220-224.

66. Kikkert and Lackenbauer, "Men of Frontier Experience," 210.

67. "The Sourdough's Favorite Beverage," Dawson Daily Nerws, August 17, 1914.

68. O’Brien was a founding member of Y.O.O.P. in Forty Mile in 1894.

69. On August 5th,1913, the Darwson Daily Nerws reported on O'Brien's business ventures and referred to him as a Sourdough. Upon his death in 1916, the Dawson Daily News also printed numerous reports and commemorations about O'Brien which referred to him as a sourdough and pioneer. "Will Put up Hotel at Donjeck," Dawson Daily Nerws, August 5, 1913.

70. Johnson, The Bonanza Narrow Gauge Railway, 5-9. This resulted in a lawsuit against O'Brien by the Nugget Express Company, which O'Brien lost.

71. Johnson, The Bonanza Narrow Gauge Railway, 20, 140.

72. It appears as though O'Brien switched parties in support of his friend and business partner Dr. Alfred Thompson, Dawson's primary physician, who was running as a Conservative candidate for parliament. According to a Dawson Daily News article outlining the Conservative platform, Thompson and the Conservatives were focused on stimulating the Yukon's economy through opening trade and business in Dawson City year-round through a Wagon Road from Whitehorse to Dawson, subsidies for steamships, reduced transportation rates, government aid for smelters and sampling mills, and year-round mail delivery. Considering O'Brien's many business ventures in the territory, it makes sense that O'Brien would favour policies that strengthened business in the Yukon and laid out plans for future economic growth. "Thompson Given Nomination," Dawson Daily Nerws, September 25, 1911.

73. Johnson, The Bonanza Narrow Gauge Railway, 5.

74. "They Want Tom O'Brien as Candidate for Yukon Council," Yukon Sun, December 13, 1902.

75. "Can Make Good Beer in Dawson," Yukon World, March 31, 1904.

76. "Yukon Order of Pioneers Funeral Notice," Dawson Daily News, August 25, 1916; "Thos. W. O'Brien is Called to His Long Rest," Dawson Daily Nerws, August 25, 1916; “Thos. W. O’Brien Laid to His Eternal Rest," Dawson Daily Nerws, August 28, 1916. 
77. The brewery was not O'Brien's only venture in modernizing the Klondike; he was also a main investor and developer in the Klondike Mines Railway-a railway set up to service mining dredges in the goldfields. In fact, when the Klondike Mines Railway opened for business, the first shipment of cargo came from the brewery into Dawson including boxes of lager, bock, and porter. Johnson, The Bonanza Narrow Gauge Railway, 33.

78. "Brewery Nearly Ready to Brew," Yukon Sun, February 10, 1904.

79. "List of Alaska Breweries," Old Breweries Information Breweriana Values, http://www.oldbreweries.com/breweries-by-state/alaska/.

80. Burley and Will, Special Brew, 26.

81. "Brewery Nearly Ready to Brew," Yukon Sun, February 10, 1904.

82. Robert Wahl and Max Henius, American Handy Book of the Brewing, Malting and Auxiliary Trades (Chicago: Wahl \& Henius, 1901), 778.

83. Jack London, John Barleycorn, Or, Alcoholic Memoirs (London: Mills \& Boon Limited, 1914).

84. Porsild, Gamblers and Dreamers, 208.

85. “Beer Season Now Open!” Dawson Daily Nerws, May 25, 1905; “Hop Distillery Nearly Finished" Yukon Sun, January 29, 1904; Dawson Daily Nerws, “Beer! Beer! Beer!” December 23, 1914.

86. Beer! Beer! Beer!” Dawson Daily News, December 23, 1904.

87. Burley and Will, Special Brew, 19.

88. Advertising beer as healthy was not unique to the Klondike Brewery. In the 1880s Sleemans advertisements alleged their beer was: "the most efficacious remedial agent of its kind for Indigestion, Dyspepsia, Loss of Appetite, General Debility, Nervous Exhaustion, Sleeplessness, Coughs, Colds, and other maladies that may result from an impaired constitution." Heron, Booze, 96.

89. "Moosehide Puts Dawson to Shame on Clean-Up," Dawson Daily Nerws, May 3, 1913.

90. Jeffrey Pilcher, "The Global Invention of Lager Beer," Seeing the Woods, November 30, 2017, https://seeingthewoods.org/2017/11/30/ the-taproom-jeffrey-pilcher/.

91. Liza Piper, "Chronic Disease in the Yukon River Basin, 1890-1960," in Locating Health, ed. Erika Dyck and Christopher Fletcher (Pickering \& Chatto Publishers, 2010): 133-34.

92. Archibald, "Grubstake to Grocery Store," 56. 
93. Michael Gates, "From the Klondike to Berlin: the Yukon in the First World War," The Northern Review 44 (2017): 9-30.

94. Gates, "From the Klondike to Berlin," 17. Women were not permitted to vote in the plebiscite.

95. Robinson, "The Home Front," 38.

96. Robinson, "The Home Front," 37.

97. Burley and Will, Special Brew, 15.

\section{Authors}

Heather Green is an assistant professor with the Department of History at Saint Mary's University in Halifax, Nova Scotia.

Matt Papai is a $\mathrm{PhD}$ student in the Department of History at Memorial University of Newfoundland.

\section{Acknowledgements}

We appreciate the assistance of archivists at the Yukon Archives and Dawson City Museum Archives. 